\title{
Teachers' sick leave due to mental and behavioral disorders and return to work
}

\author{
Amanda Aparecida Silva ${ }^{\mathrm{a},{ }^{*}}$ and Frida Marina Fischer ${ }^{\mathrm{a}}$ \\ ${ }^{a}$ Dep Environmental Health, School of Public Health, University of São Paulo, Av. Dr. Arnaldo, 715, SP, Brazil
}

\begin{abstract}
This manuscript presents a review of the literature about medical leaves due to mental and behavioral disorders and return to work of teachers. There are scarce published manuscripts. Most articles relate with prevalence of mental disorders and factors associated with the work organization, and did not mention intervention proposals and or changes in the work organization and teaching work. Proposed actions are discussed.
\end{abstract}

Keywords: mental health, teaching, work organization, medical leave, return to work.

\section{Introduction}

Studies about teachers provided important evidences about the prevalence of mental health problems and associated factors [10,13,31]. In accordance to the Brazilian Ministry of Social Welfare [20], mental and behavioral disorders are the third leading cause of absenteeism from work. Based in a longitudinal study, D'Amato and Zijlstra [1] concluded that predictors of return to work for employees whose absences were due to physical health ailments are different from those who were on medical leave due to mental health problems.

Teaching has interactions between the subjects and the conditions under which work activities are carried out and is subject to management mechanisms [5]. Studies on withdrawal and return to work usually discuss time-off work and disability rather than other work-related workers' issues [16,17].

It is often seen workers coming back to the same working conditions that were associated with their withdrawal from work. This also occurs in the educational system, and can lead to a worsening of the health symptoms [18]. This manuscript presents a brief review of the literature, particularly sick leave of teachers due to mental and behavioral problems.

\section{Methodology}

The literature was reviewed in the first half of 2011 using the database of BVS/BIREME. LILACS and MEDLINE were included as well. The selected articles were available in full and written in Portuguese, English and Spanish. The health science descriptors were employed (DeCs/MeSH): sick leave, state of return, work, leave, mental health, mental and behavioral disorders, occupational health. These terms were always grouped to following descriptors: teacher or professor\$. Specifically in LILACS and MEDLINE we used the free search mode with the terms "retorno ao trabalho" ("return to work") in Portuguese (LILACS) and "return to work" grouped with term "teacher" in English (MEDLINE). Publication dates were not restricted.

\section{Results}

The search yielded about 330 references and $6 \%$ $(n=20)$ were selected. The excluded articles were based on the following criteria: health condition not discussed (psychic, behavioral or mental health disorders), main subject being the student and learning

\footnotetext{
*Corresponding author. E-mail: amandaas@usp.br.
} 
conditions, not referring to teaching work, not available in full length. Of the articles selected, $25 \%(n=5)$ in fact referred to the process of withdrawal and return to work for mental and behavioral disorders in the population of interest $[4,12,14,19,29]$. The studies were delimited as follow: transversal [12], casecontrol [4] cohort [14], documentary research [29] and one essay [19]. Among these, only one study aimed the Brazilian population [29]. In two articles the process of withdrawal and return to work was compared to other populations [12,14]. The other articles discussed working conditions, prevalence of mental health problems and/or the association between socio-demographic factors and work with the observed health conditions [7-9,11,13,2124,26,30-34]. Most of manuscripts comprised crosssectional epidemiological studies.

\section{Discussion}

A set of diseases were similarly identified but were labeled differently. Some terms used had a broad meaning such as symptoms of stress, mental health. The diversity of definitions used for mental health problems poses difficulty to research the area and perhaps even checking evidence in relation to psychosocial work factors [16,17]. Burnout syndrome was the subject of five epidemiologic manuscripts [29,31]. Several studies were conducted on health and teaching workers in Bahia, Brazil [7-8,24,31-32]. The prevalence of psychiatric disorders in the populations studied in Bahia was considered high, ranging from $20 \%$ to $55 \%$ [31]. These data are similar to those found in other areas of the country.

Differences in working conditions and health among men and women have been reported. The women reported worse working conditions and constituted the group with the highest prevalence of mental and behavioral disorders [21,31,32]. There was no conformity between the results of studies regarding the prevalence of these disorders in teachers compared to other populations $[9,34]$. In epidemiological studies, most of the variables tested with the various outcomes are variables of work organization. The main variables of teachers' work-related outcomes were: lack of support from co-workers, relationships with students, expectations of family, some behaviors of students, number of students served, content and characteristics of the task, repetitive work, fast pace, development of activities without proper material structure, uneasy atmosphere, high psycho- logical demands, lack of autonomy planning activities, lack of participation in institutional decisions, lack of perspective on career development, profession less interesting than when he/she started working, low pay, long working hours, chronic stressors, job dissatisfaction, working time, work in urban areas, active work and high demand, according to the demand-control model. It is important to consider the context of these factors to understand their meaning, degree of occurrence and, relationships with health outcomes. Eg. Mahan et al [26] suggest that states of anxiety and depression depend whether the frequency of episodic or chronic stressors in teaching jobs.

Authors mentioned changes are required in the workplace $[11,23,29,31]$ but there are few concrete proposals for changes. Carlotto and Palazzo [23] were more specific in proposing the existence of programs aimed at management teams and teaching which could foster discussion and reflection. As Gasparini et al [29], these authors concluded that changes in the system and public policy education determine the working conditions of teachers.

Two manuscripts compared similar aspects of the withdrawal processes and return to work, but the methodologies and discussion were distinct. Both used under representatives samples due to low rates of return of questionnaires $[4,12]$. Age was identified in two articles as an important aspect of withdrawal and return to work. In a case-control study, it was found that after 45 years of age there was an increase in the risk of medical leaves due to psychic disorders among teachers. Return to work was also associated with age. There was no statistical difference in relation to the profession [4]. Brown et al [12] showed that teachers walked away with younger age and less use of health care compared to health professionals. Options to work in another activities and a rehabilitation program in the workplace occurred but in reduced frequency for teachers. The reduction of working hours was a strategy used by teachers prior to their medical leave [12]. These authors pointed out the difficulties of alternative activities in the school environment that are compatible with teaching activities. In addition to age, disease registry systems for work and pensions influence the incidence of withdrawal and the trajectories of the teachers to return.

Smith [19] corroborates Brown [12] stating that many absences could be avoided or decreased its duration. The characteristics of those involved, especially in the administration, and cultural factors are decisive on these aspects. Nevertheless, in a cohort study with follow-up of 1 year [14], it was observed 
that the return to work was reinforced by a positive outlook of the worker on his return. The duration of the time off-work was also influenced by previous experiences and environments at home and at work. Personal and social aspects are important factors in the process of withdrawal and return to work.

In this review, studies were confined to the predictors of both positive and negative aspects. It is necessary to move forward in the proposals for concrete changes that focus into the characteristics of teaching and the health condition. Neieuwenhuijsen et al [14] suggest that the return to work is more difficult for professionals whose activities are complex, as in teaching. Taking into account the occupational health perspective, it is relevant to carry out investigations about work conditions before and after returning to work. In order to keep workers healthy it is required improvements of the work environment and work processes, aiming not only elimination of risks but meaningful and rewarding work life

\section{Acknowledgments}

Amanda A. Silva receives a scholarship from FAPESP (2010/11698-0).

\section{References}

[1] A. D'Amato, and F. Zijlstra, Toward a climate for work resumption: the nonmedical determinants of return to work. J Occup Environ Med, 52 (2010), 67-80.

[4] C. Solomon, J. Poole, K.T. Palmer, D. Coggon, Health-related job loss: findings from a community-based survey, Occup Environ Med, 64 (2007), 144-149.

[5] D.A. Oliveira, A reestruturação do trabalho docente: precarização e flexibilização, Educ. Soc., 259 (2004), $1127-$ 1144.

[7] E.J.F.B. Reis, F.M. Carvalho, T.M. Araújo, L.A. Porto, A.M.S Neto, Trabalho e distúrbios psíquicos em professores da rede municipal de Vitória da Conquista, Bahia, Brasil, Cad Saúde Pública, 21 (2005), 1480-1490.

[8] E.J.F.B. Reis, T.M. Araújo, F.M. Carvalho, L. Barbalho, M.O. Silva, Docência e exaustão emocional, Educ. Soc, 27 (2006), 229-253.

[9] H. Sveinsdóttir, H. Gunnarsdóttir, H. Fridriksdóttir, Selfassessed occupational health and working environment of female nurses, cabin crew and teachers, Scand J Caring Sci, 21 (2007), 262-273.

[10] I.S. Schonfeld, A longitudinal study of occupational stressors and depressive symptoms in first-year female teachers, Teaching teacher education, 8 (1992), 151-158.

[11] J. Bauer, A. Stamm, K. Virnich, K. Wissing, U. Muller, M. Wirsching, U. Schaarschmidt, Correlation between burnout syndrome, psychological and psychosomatic symptoms among teachers, Int Arch Occup Environ Health, 79 (2006), 199-204.
[12] J. Brown, W.H. Gilmour, E.B. Macdonald, Return to work after ill-health retirement in Scottish NHS staff and teachers, Occup Med, 56 (2006), 480-484.

[13] J.B.V. Batista, M.S. Carlotto, A.S. Coutinho, L.G.S. Augusto, Prevalência da Síndrome de Burnout e fatores sociodemográficos e laborais em professores de escolas municipais da cidade de João Pessoa, PB, Rev bras epidemiol, 13 (2010), 502-512.

[14] K. Nieuwenhuijsen, J.H. Verbeek, A.G.E.M. Boer, R.W.B. Blonk F.J.H. van Dijk, Predicting the duration of sickness absence for patients with common mental disorders in occupational health care, Scand J Work Environ Health, 32 (2006), 67-74.

[16] L. Blank, J. Peters, S. Pickvance, J. Wilforce, E. MacDonald, A systematic review of the factors which predict return to work for people suffering episodes of poor mental health, J Occup Rehab, 18 (2008), 27-34.

[17] L.R. Cornelius, J.J. van der Klink, J.W. Groothoff, S. Brouwer, Prognostic factors of long term disability due to mental disorders: a systematic review, J Occupl Rehab, 21 (2011): 259-274.

[18] M. Juracy, T. Siqueira, E.S. Ferreira, Saúde das professoras das séries iniciais: o que o gênero tem a ver com isso? Psicol., Ciênc. Prof., 23 (2003), 76-83.

[19] M.E. Smith, Work phobia and sickness leave certificates, Afr J Psychiatry, 12 (2009), 249-253.

[20] Ministério da Previdência Social. Acompanhamento mensal dos benefícios auxílios-doença acidentário concedidos, segundo os códigos da CID-10 janeiro a novembro de 2009. Brasília. 11/1/2010. Available at http://www.mpas.gov.br/arquivos/office/4 100111-115548-51

[21] M.G.A. Rodriguez, M.L. Serrano, S.A.F. Chávez, J.A. Pérez, C.A. Beltrán, Factores psicosociales laborales y sínddrome de burnout, diferencias entre hombres y mujeres docentes de secundaria, zona metropolitan de Guadalajara, México, Ciencia \& Trabajo, 30 (2008), 138-142.

[22] M.R.P. Mascarello e M.E.B.Barros, Nos fios de Ariádne: cartografia da relação saúde-trabalho numa escola pública de Vitória de Vitória, Rev Bras Educ, 12 (2007), 104-181.

[23] M.S. Carlotto, L.S. Palazzo, Síndrome de burnout e fatores associados: um estudo epidemiológico em professores, Cad Saúde Pública, 22 (2006), 1017-1026.

[24] N.S. Delcor, T.M. Araújo, E.J.F.B. Reis, L.A. Porto, F.M. Carvalho, M.O. Silva, L. Barbalho, J.M. Andrade, Condições de trabalho e saúde dos professores da rede particular de ensino de Vitória da Conquista, Bahia, Brasil, Cad Saúde Pública, 20 (2004), 187-196.

[26] P.L. Mahan, M.P. Mahan, N.H. Park, C. Shelton, K.C. Brown, M.T. Weaver, Work environment stressors, social support, anxiety, and depression among secondary school teachers, AAOHN, 58 (2010), 197-205

[29] S.M. Gasparini, S.M. Barreto, A.A. Ávila. O professor, as condições de trabalho e os efeitos sobre sua saúde, Educ. Pesqu, 31 (2005), 189-199.

[30] T.G. Vedovato e M.I. Monteiro, Perfil sociodemográfico e condições de saúde e trabalho dos professors de nove escolas estaduais paulistas, Rev Esc Enf USP, 42 (2008), 290-297.

[31] T.M. Araújo and F.M. Carvalho, Condições de trabalho docente e saúde na Bahia: Estudos epidemiológicos, Educ. Soc, 30 (2009), 427-449.

[32] T.M. Araújo, T.M. Godinho, E.J.F.B. Reis, M.M.G. Almeida, Diferenciais de gênero no trabalho docente e repercussões sobre a saúde, Ciênc saúde colet., 11 (2006), 1117-1129.

[33] T.W. Taris, P.J.G. Schreurs, M.C.W. Peelers, P.M. Le Blanc, W.B. Schaufeli, From inequity to burnout: the role of job stress, J Occup Health Psychol, 6 (2001), 303-323. 
[34] V. Kovess-Masféty, C. Sevilla-Dedieu, C. Rios-Seidel, E.

Nerriere, C.C. Chee, Do teachers have more health problems?

Results from a French cross-sectional survey, BMC Public

Health, 6 (2006): 101. 